\title{
Local Antibiotic Therapy in the Treatment of Bone and Soft Tissue Infections
}

\author{
Stefanos Tsourvakas \\ Orthopedic Department, General Hospital of Trikala
}

Greece

\section{Introduction}

Bone and soft tissue infections are serious problems in orthopedic and reconstructive surgery. Especially, chronic osteomyelitis is a difficult infection to treat and eradicate. Long term parenteral antibiotics with multiple surgical debridements are often required for effective therapy (Cierny \& Mader, 1984). Therefore, it is understandable that continuous efforts are being made and complete one or other element in the treatment of bone and soft tissue infections.

There is a long history of local antibiotic use for the treatment of bone and soft tissue infections. During World War I, Alexander Fleming observed that locally applied antiseptics failed to sterilize chronically infected wounds, but they did reduce the burden of bacteria (Fleming, 1920). In 1939, the instillation of sulfanilamide crystals, along with thorough debridement, hemostasis, primary closure and immobilization, resulted in a reduced infection rate for open fractures (Jensen et al, 1939). As additional systemic antimicrobial agents became available, interest in the topical treatment of wounds waned, but the management of established osteomyelitis remained problematic. In the 1960s, the method of closed wound irrigation-suction was popularized as a method which could be used to deliver high concentrations of an antibiotic after debridement (Dombrowski \& Dunn, 1965). An alternative method for delivering high concentrations of an antibiotic to sites of lower extremity osteomyelitis was isolation and perfusion (Organ, 1971).

The delivery of local antibiotics for the treatment of musculoskeletal infection has become increasingly popular for a variety of reasons. The basis for developing and using local antibiotic delivery systems in the treatment of bone and soft tissue infection is either to supplement or to replace the use of systemic antibiotics. High local levels of antibiotics facilitate delivery of antibiotics by diffusion to avascular areas of wounds that are inaccessible by systemic antibiotics and in many circumstances the organisms that are resistant to drug concentrations achieved by systemic antibiotic are susceptible to the extremely high local drug concentrations provided by local antibiotic delivery.

The local use of antibiotics to prevent and treat bone and soft tissue infections was revived in Germany with the widespread use of prosthetic joint replacement, a situation in which infections were not anticipated consequence of trauma or sepsis but a devastating complication of elective surgery (Buchholz \& Engelbrecht, 1970). However, it is from the 
year 2000 that research on local delivery of antibiotics to bone has gained considerable attention. Note that the numbers of publications in the last five years are double and decuple published in earlier decades (Soundrapandian et al, 2009).

Bacterial infection in orthopedic and reconstructive surgery can be devastating, and is associated with significant morbidity and poor functional outcomes (Haddad et al, 2004). Operative treatments (excision of infected and devascularized tissues, obliteration of dead space, restoration of blood supply and soft tissue coverage, stabilization and reconstruction of the damaged bone), removal of all foreign bodies and systemic antimicrobial therapy are three crucial components of the treatment of these cases (Lazzarini et al, 2004). A long-term course of systemic antibiotherapy has been considered essential, but these prolonged therapies can result in side effects or toxicity. In order to achieve therapeutic drug concentration in the affected area, high systemic doses are generally required which can further worsen toxic side effects (Nandi et al, 2009). Antibiotic treatment may be inadequate or ineffective in patients with poorly vascularized infected tissues and osteonecrosis, which is often present in cases of osteomyelitis. Moreover, normal doses of systemic antibiotics may be insufficient to breach the glycocalyx or biofilm produced by the infecting bacteria (El-Husseiny et al, 2011). Despite intensive therapy, advances in surgical techniques, and development of new antimicrobials, relapse rate are still significant and treatment of bone and soft tissue infections remain challenging.

New methods such as local delivery of antibiotics have evolved in an attempt to improve the prognosis of patients with musculoskeletal infections. The use of local antibiotic delivery system has become an accepted treatment method that continues to evolve for a variety of reasons. There has been an explosion of new technologies that are designed to facilitate the delivery of local antibiotics in new and creative ways. The primary reason for using these local antibiotic delivery vehicles is the ability to achieve very high local concentrations of antibiotics without associated systemic toxicity. In the typical infected wound environment, which frequently has zones of avascularity, the ability to achieve high levels of antibiotics in these otherwise inaccessible areas is highly desirable (Cierny, 1999). Additional reasons for use of these delivery vehicles include the desire to treat remaining plactonic organisms and sessile organisms in biofilms more effectively with high concentrations of antibiotics (Hanssen et al, 2005). Because bone regeneration often is required as a part of the treatment plan, a recent trend has been simultaneously to provide a frame work of osteoinductive and osteoconductive materials along with antibiotics (Gitelis \& Brebach, 2002).

Despite the rapid acceptance of these antibiotic delivery vehicles, there are many unanswered questions related to their use, particularly when viewed within the environment of biofilms. Considerable investigation and development still are required to develop the necessary data to help determine a number of unknown variables associated with the use of local antibiotic delivery systems. In the application of a local antibiotic therapy for bone and soft tissue infections the following aspects should be considered: a) delivery technique; b) type of antibiotic that can be used; $c$ ) pharmacokinetics; d) possibility of application to a coating and to fillers; e) possibility of combination with osteoconductive and osteoinductive factors; f) use as prophylaxis and/or therapy; g) drawbacks.

This review introduces bone and soft tissue infection-its present options for drug delivery systems and their limitations, and the wide range of carrier materials and effective drug choices. Also, I will describe and contrast the different local antibiotic delivery vehicles to 
provide a context for their current clinical use and to discuss the emerging investigate and developmental directions of these biomaterials.

\section{Criteria for the production of a local delivery system for antimicrobial agents}

Despite the reduction in the risk of contamination due to improved material, implant, and clean room technique as well as peri-operative antibiotic prophylaxis, infections still remain a feared complication in orthopedic and reconstructive surgery (Taylor, 1997). In many surgical disciplines, topical administration of antibacterial drug is not possible or practicable, and achieving of a sufficient antibacterial dose by systemic delivery may lead to adverse reactions negatively influencing overall patient's $\mathrm{c}$ by conditions. Especially the use of specific antibiotics may be limited by their high cumulative cell and organ toxicity (Ruszczak \& Friess, 2003). Moreover, insufficiency in local blood supply due to posttraumatic or post-operative tissue damage as well as inadequate tissue penetration or bacterial resistance increase the local ineffectiveness of systemic antibiotic therapy, both in terms of preventive or curative drug administration (Mehta et al, 1996). This dilemma can be resolved by local delivery of antibiotics.

The ideal local drug delivery system has been a pursuit of scientists and physicians for the past fifty years. The concept of delivering drugs locally to the area of disease rather than through the systemic circulation without the concomitant secondary systemic complications is appealing both physiologically and psychologically (Nelson, 2004). The ideal local antibiotic delivery system would produce high antibiotic levels at the site of infection and safe drug levels in the systemic circulation. Antibiotic levels would need to be controlled to allow the systemic to be either therapeutic, bellow the toxic level, or absent, and to allow these features to be controlled independently from each other. Furthermore, the antibiotic elution curves, the factors that influence elution, and the most suitable local delivery system for the environment into which the material is to be placed, would need to be known. These materials would need to be easily placed, easily removed or changed, patient friendly and inexpensive. According to Hanssen, the ideal local antibiotic delivery system "would provide a more efficient delivery of higher levels of antibiotics to the site of infection and yet minimize the risks of systemic toxicity associated with traditional methods of intravenous antibiotics" (Hanssen, 2005).

\subsection{Carrier materials for local antibiotic delivery}

The consequent need for local drug delivery has been recognized since many years. During the last decades, different forms of local antibiotic delivery have been used. The most common and simple way was to spread the drug in a powder form over the wound area after an extensive debridement and before wound closure (Rushton, 1997). Consequently, high local concentrations for a short period of time are achieved which potentially result in tissue damage. Another approach was to applied antibiotics in liquid form by injection or irrigation or, to extend the effectiveness by continuous perfusion. However, this method is labor intensive and requires experienced nursing staff to avoid leakage and drain blockage. Furthermore, the use of implantable pumps which can be refilled percutaneously is described (Perry \& Pearson, 1991). An additional method used was to soak the cotton gauze or linen operative material with the antibiotic and leave it in the wound until the final closure. This procedure is still in use in many countries to minimize the post-operative risk of infection, e.g. in dirty abdominal wounds or in trauma patients. 
Although the ideal local antibiotic delivery system has not been discovered, several promising materials are present in modern research. The most common carrier systems of antibiotics that successfully release the drug according to prescribed dosage are listed in Table 1.

\begin{tabular}{|c|c|c|}
\hline Carrier System & Antibiotic Released & References \\
\hline \multicolumn{3}{|l|}{ Non-biodegradable } \\
\hline \multirow[t]{4}{*}{ 1. Bone cement } & Gentamicin & $\begin{array}{l}\text { Baker \& Greenham, 1988; } \\
\text { Buchholz et al, } 1984\end{array}$ \\
\hline & Vancomycin & Kuechle et al, 1990 \\
\hline & Cefazolin & Marks et al, 1976 \\
\hline & Ciprofloxacin & Tsourvakas et al, 2009 \\
\hline \multirow[t]{4}{*}{ 2. Bone cement beads } & Gentamicin & $\begin{array}{l}\text { Buchholz et al, 1984; } \\
\text { Mendel et al, } 2005\end{array}$ \\
\hline & Tobramycin & Seligson et al, 1993 \\
\hline & Cefuroxime & Mohanty et al, 2003 \\
\hline & Vancomycin & Chohfi et al, 1998 \\
\hline \multicolumn{3}{|l|}{ Biodegradable } \\
\hline \multirow[t]{2}{*}{ 1. Plaster of Paris pellets } & $\begin{array}{l}\text { Gentamicin Santschi \& } \\
\text { McGarvey, } 2003\end{array}$ & \\
\hline & Teicoplanin & Dacquet et al, 1992 \\
\hline 2. Collagen-Sponge & Gentamicin & Ruszczak \& Friess, 2003 \\
\hline \multirow[t]{2}{*}{ 3. Fibrin-sealant } & Cefazolin & Tredwell et al, 2006 \\
\hline & Ciprofloxacin & Tsourvakas et al, 1995 \\
\hline 4. Hydroxyapatite blocks & Vancomycin & Shirtliff et al, 2002 \\
\hline \multirow[t]{3}{*}{$\begin{array}{l}\text { 5. Polylactide/polyglycolide } \\
\text { implants }\end{array}$} & Gentamicin & Garvin et al, 1994b \\
\hline & Ciprofloxacin & Koort et al, 2008 \\
\hline & Vancomycin & Calhoun \& Mader, 1997 \\
\hline 6. Dilactate polymers & Fluoroquinolones & $\begin{array}{l}\text { Dounis et al, 1996; } \\
\text { Kanellakopoulou et al, } \\
1999\end{array}$ \\
\hline 7. Cancellous bone & $\begin{array}{l}\text { Vancomycin, } \\
\text { Ciprofloxacin }\end{array}$ & Witso et al, 2000 \\
\hline 8. Calcium Sulfate & Tobramycin & Nelson et al, 2000 \\
\hline 9. Calcium phosphate cement & Teicoplanin & Lazarettos et al, 2004 \\
\hline \multicolumn{3}{|l|}{ Miscellaneous } \\
\hline 1. Fibres & Tetracycline & Tonetti et al, 1998 \\
\hline 2. Chitosan & Vancomycin & Chevher et al, 2006 \\
\hline 3. Biomedical polyourethanes & Gentamicin, Ciprofloxacin & Schierholz et al, 1997 \\
\hline
\end{tabular}

Table 1. Carriers used for local delivery of antibacterial agents

Drug delivery carriers developed for local delivery of antibiotics can be divided into nonbiodegradable and biodegradable carriers (Kanellakopoulou \& Giamarellos-Bourboulis, 2000). Non-biodegradable delivery systems such as polymethylmethacrylate (PMMA) 
beads containing gentamicin have been approved for use in treatment of osteomyelitis in Europe (Klemm, 2001; Seligson et al, 1993). Antibiotic-loaded bone cement represent the current gold standard for local antibiotic delivery in orthopedic surgery (Nelson, 2004). This product has been proven to be efficacious but suffers from the major drawback of requiring subsequent operation to remove the bone cement beads at the completion of antibiotics release.

In recent years, various biodegradable delivery systems have been developed and evaluated for local delivery of antibiotics in the treatment of bone and soft tissue infections (Garvin et al, 1994b; Gursel et al, 2000). One of the primary advantages of a biodegradable system is the avoidance of secondary surgical procedures to remove foreign materials, such as bone cement, once antibiotic elution has ceased. Biodegradable implants could provide high local bactericidal concentrations in tissue for the prolonged time needed to completely eradicate the infection and the possibility to match the rate of implant biodegradability according to the type of infection treated (Kanellakopoulou \& Giamarellos-Bourboulis, 2000). Biodegradation also makes surgical removal of the implant unnecessary. The implant can also be used initially to obliterate the dead space and, eventually to guide its repair. Additional possibilities with the use of biodegradable systems include variation in the magnitude and duration of antibiotic delivery as well as the potential for purposely adjusting the wound environment with breakdown products of some biodegradable materials (Hanssen, 2005).

Additional methods have included adding antibiotics to bone graft and to bone substitutes (Li \& Hu, 2001; Shinto et al, 1992; Witso et al, 2000) or other naturally occurring polymers (Kawanabe et al, 1998) whereby the antibiotic is adsorbed to the surface of these materials and is then released into the wound environment. These materials can be include to the biodegradable antibiotic carriers.

The major drawback associated with non-biodegradable systems is the need to remove from the application site upon completion of their task. This removal surgery is usually more difficult than the implantation because of local tissue scaring and adhesion and may lead to postoperative infection due to both the patient local and systemic condition. In addition, the second procedure poses the risk of additional pain, anesthetic complications, and inferring extra costs. Recently, a Dutch group of scientists has found that despite of antibiotic release, cement beads act as a biomaterial surface at which bacteria preferentially adhere, grow and potentially develop antibiotic resistant (Neu et al, 2001).

\subsection{Antibiotic selection}

In order to select the appropriate antibiotic, an understanding of the microbiology of bone and soft tissue infections is imperative. Normal bone is highly resistant to infection, which can only develop as a result of trauma, very large inocula, or due to the presence of foreign material. Irrespective of the advancement in making surgeries and prosthesis, available sterile, and achieving aseptic conditions in operation theatres, infection associated with major trauma or surgeries are still unavoidable. Due to their application for prophylaxis and therapeutic antibiotics need to be applied to bone in every case of trauma or surgery, in addition to cases of bone and soft tissues infections. When the microbial load has crossed a critical density, they form biofilms that are quite hard for antibiotics to penetrate, often resulting in relapse of infection (Fux et al, 2005). Very high concentrations of antibiotics are 
required to eradicate them, which could hardly be attained by conventional routes of delivery without serious side effects.

The most commonly described microbes to cause bone and soft tissue infections, especially chronic osteomyelitis, are staphylococcus aureus; Group A beta hemolytic streptococcus and gram-negative bacteria, particularly Enterobacteriaceae and Pseudomonas aeruginosa (Galanakis et al, 1997; Rissing et al, 1997).

Numerous of antibiotics are available for use in antibiotic impregnated carriers. Considering the above criteria and on bacteriological finding in bone and soft tissue infections, the most acceptable agents in local delivery systems are aminoglycosides and to a lesser extent various $\beta$-lactam agents and quinolones (Rushton, 1997). A combination therapy of antibiotics is useful to reduce the toxicity of individual agents, to prevent the emergence of resistance and to treat mixed infections involved in chronic osteomyelitis (Mader et al, 1993). However, specific characteristics should be considered before the antimicrobial agents selected for use in local delivery systems: the antibiotic should be stable at body temperature and water soluble to ensure diffusion from the carrier; be active against the most common bacterial pathogens involved in bone and soft tissue infections; be locally released at concentrations exceeding several times (usually 10 times) the minimum inhibitory concentration (MIC) for the concerned pathogens; be unable to enter in systemic circulation; have a low rate of allergic reaction; a low rate of primary resistance; not produce supra infection and be readily available in powder form (Kobayashi et al, 1992; Popham et al, 1991). The choice of different classes of antibiotics for clinical use must be made according to a microbiologic sensitivity test (Popham et al, 1991; Ueng et al, 1997).

Antibiotics in general are hydrophilic drugs, hardly exhibit stability problems (except a few as cephalosporins) making them suitable to load with any kind of composite. Release of antibiotics shall depend on various factors. Release of the antibacterial agent in such systems is governed by the rate of dissolution of the drug in its matrix allowing its penetration through the pores of the carrier. For highly soluble agents, e.g. $\beta$-lactams agents, the amount of released drug depends on the surface area of the carrier and on the initial concentration of the drug in the prepared system. For relatively insoluble agents, e.g. quinolones, the rate of drug release depends on the porosity of the matrix and on dissolution of the drug in the matrix (Allababidi \& Shah, 1998). However, insufficient release of antibiotics on the basis of time and concentration could lead to development of resistant strains and growth of microorganisms on the surface of the scaffolds (Soundrapandian et al, 2009).

\section{Non-biodegradable systems}

Antibiotic-impregnated non-biodegradable beads mainly polymethylmethacrylate (PMMA) have been widely used for the local administration of antibiotics. Buchholz and Engelbrecht in 1970 proposed delivering antibiotics to an infected site via elution of antibiotics from antibiotic-impregnated cement placed adjacent to the site of infection. The use of antibioticimpregnated polymethylmethacrylate (PMMA) cement bead for the treatment of bone and soft tissue infections has many theoretical advantages. The beads, which release antibiotics by passive diffusion, combine with high local concentrations with low systemic levels of the antibiotic (Henry \& Galloway, 1995), leading to more effective killing of the organisms and less risk of systemic toxicity. In addition, the beads can fill the dead space that may be left after debridement of infected tissue (Patzakis et al, 1993). 


\subsection{Antibiotic-loaded bone cement (PMMA)}

Antibiotic impregnated beads have been employed in the treatment of bone and soft tissue infections for nearly 30 years; their use is well established in many European centers (Jenny, 1988). For the first time, antibiotic-loaded bone cement was used as a prophylactic agent against deep bone infections in orthopedic endoprosthetic surgery in human patients (Buchholz et al, 1984). Since then antibiotic-loaded bone cement has been an effective method for providing sustained high concentrations of antibiotics locally when used in numerous types of bone and soft tissue infections (Calhoun \& Mader, 1989; Josefsson et al, 1990). Polymethylmethacrylate (PMMA) exist in two forms: that of antibiotic-impregnated bone cement applied in arthroplasties and antibiotic-impregnated bead chains for musculoskeletal infections (Henry \& Galloway, 1995). The success of these carriers depend on two factors: PMMA does not usually trigger any immune response from the host and the form of a bead confers a wide surface area, allowing rapid release of the antibiotic.

Several factors influence the elution of antibiotics from PMMA cement. In addition to the type of antibiotic used, the type of cement also influences elution (Marks et al, 1976). Factors that increase the porosity of the cement (such as the addition of dextran or higher concentrations of antibiotic) also increase elution (Patzakis \& Wilkins, 1989). Walenkamp in 1989 , showed that the size of the bead influenced the amount of antibiotic that can be eluted. Small or mini beads provide better elution than larger beads, probably because of a more favorable surface to volume ratio (Holtom et al, 1998). Finally, the turnover of the fluid surrounding the beads will influence the local concentration as well as the maximum amount of antibiotic eluted.

Polymethylmethacrylate cement is available in various commercial and non-commercial brands and in-vitro elution of antibiotics from these varies between brands (Greene et al, 1998). Commercially available beads have a consistent diameter of $7 \mathrm{~mm}$ and are available in stands of 10 or 30 (Nelson et al, 1992). Noncommercial preparations are generally prepared by the surgeons themselves. The main disadvantages associated with beads are improper mixing of antibiotic into the beads and a lack of the uniform size of bead, resulting in lower antibiotic availability (Nelson et al, 1992). Selection of antibiotic in commercially prepared beads depends on its stability at the high temperatures (up to $100^{\circ} \mathrm{C}$ ) at which polymerization of bone cement occurs. The aminoglycosides are heat stable and are thus extensively used in these preparations. It has been documented for human being and invitro studies that elution of antibiotics from PMMA is bimodal (Henry et al, 1991). Approximately $5 \%$ of the total amount of antibiotic is released within the first 24 hours from the surface of beads or rods, followed by a sustained elution of antibiotic that diminishes during subsequent weeks or months. Elution properties of polymethylmethacrylate bone cement depend on the type of PMMA, type and concentration of antibiotic and structural characteristics of the bead or rods (Henry et al, 1991). Gas sterilization does not affect the properties of antibiotics or elution properties of PMMA (Henry et al, 1993).

There have been many in-vitro studies on the diffusion or elution of antibiotics from polymethylmethacrylate bone cement. Several different antimicrobial agents have been studied, including the aminoglycosides, primarily gentamicin but also tobramycin, amikacin and streptomycin (Greene et al, 1998; Masri et al, 1995; Wahlig et al, 1978), 
cephalosporins including cefazoline, cefotaxime, ceftriaxone and ceftazidime (Alonge \& Fashina, 2000; Tomczak et al, 1989; Wilson et al, 1988), vancomycin (Kuechle et al, 1991) and ciprofloxacin (Tsourvakas et al, 2009). All antimicrobial agents go through an initial phase during which the concentration of fluid surrounding the beads or cement spacers is very high, followed by a gradual decrease to sustained low levels for many weeks or months. Although there are differences in elution between each different antimicrobial agent, all seem to have adequate elution for the treatment of bone and soft tissue infection, but the length of time that the drug levels remain above the minimum inhibitory concentration for the target organism (usually Staphylococcus aureus) varies depending on the drug selected and the conditions of the experiment. Cumulative data on the in-vitro elution of antibiotics in polymethylmethacrylate bone cement are presented in table 2, where it is clearly shown that both aminoglycosides and quinolones are released at very high concentrations, but the peak of release occurs on the first day. As the viscosity of PMMA decreases, the amount of released antibiotic increases (Bunetel et al, 1990). The same first day peak was also documented for tobramycin and vancomycin (Brien et al, 1993); the release lasted for a total period of only one week.

\begin{tabular}{|c|c|c|l|}
\hline Antibiotic-loaded & $\begin{array}{c}\text { Duration of } \\
\text { release }\end{array}$ & $\begin{array}{c}\text { Peak of release } \\
(\mu \mathrm{g} / \mathrm{ml})\end{array}$ & \multicolumn{1}{|c|}{ Study } \\
\hline PMMA & $($ days $)$ & $/$ day of peak & \\
\hline Gentamicin & 56 & $318.6 / 1$ & Hoff et al, 1981 \\
\hline Tobramycin & 220 & $>250 / 1$ & Mader et al, 1997 \\
\hline Clindamycin & 220 & $>250 / 1$ & Mader et al, 1997 \\
\hline Vancomycin & 12 & $>200 / 1$ & Mader et al, 1997 \\
\hline Cefazolin & 28 & $250 / 1$ & Adams et al, 1992 \\
\hline Penicillin & 91 & $199.5 / 1$ & Hoff et al, 1981 \\
\hline Ciprofloxacin & 360 & $80.8 / 1$ & Tsourvakas et al, 2009 \\
\hline Amikacin & 5 & $200 / 1$ & Kuechle et al, 1990 \\
\hline
\end{tabular}

Table 2. Characteristics of the in-vitro elution of different antibiotics from PMMA bone cement

To achieve adequate killing of bacteria, beads should not be used in combination with an irrigation system, and moisture should be excluded by artificial skin. With these precautions the amount of gentamicin releasd by the bone cement beads does not exceed $25 \%$ of the total amount implanted (Rushton, 1997). In chronic osteomyelitis, healing of the wound expected within 10 days but PMMA beads may remain implanted for up to 4 weeks, after his surgical removal is necessary followed by osseous reconstructive surgery. The need for removal is the major disadvantage of the beads, although in some patients small chains of beads be removed in the ward via a small skin incision (Walenkamp, 1997).

Antibiotic-loaded bone cement can be applied either in infected arthroplasties or as surgical prophylaxis during joint arthroplasties. Cumulative results of clinical studies involving its application for both purposes are given in table 3 . 


\begin{tabular}{|l|l|c|c|c|}
\hline \multicolumn{1}{|c|}{ Study } & \multicolumn{1}{|c|}{$\begin{array}{c}\text { Purpose of } \\
\text { application }\end{array}$} & Patients & $\begin{array}{c}\text { Favorable } \\
\text { outcome } \\
(\%)\end{array}$ & $\begin{array}{c}\text { Follow-up } \\
\text { ( months) }\end{array}$ \\
\hline Josefsson et al, 1990 & $\begin{array}{l}\text { Prophylaxis in total } \\
\text { hip arthroplasty }\end{array}$ & 1688 & 99.2 & 60 \\
\hline Garvin et al, 1994a & $\begin{array}{l}\text { Periprosthetic hip } \\
\text { infection }\end{array}$ & 40 & 95 & 17 \\
\hline Hanssen et al, 1994 & $\begin{array}{l}\text { Infected knee } \\
\text { prosthesis }\end{array}$ & 183 & 84.2 & 93 \\
\hline Whiteside, 1994 & $\begin{array}{l}\text { Infected knee } \\
\text { prosthesis }\end{array}$ & 33 & 96.9 & 24 \\
\hline Raut et al, 1995 & $\begin{array}{l}\text { Infected knee } \\
\text { prosthesis }\end{array}$ & 86 & 89.6 & 52 \\
\hline Cho et al, 1997 & $\begin{array}{l}\text { Chronic } \\
\text { osteomyelitis }\end{array}$ & 31 & 87 & 36 \\
\hline
\end{tabular}

Table 3. Cumulative data from clinical trials with antibiotic-loaded PMMA bone cement

The primary basis for use of antibiotic-loaded polymethylmethacrylate bone cement as a prophylactic method to reduce the prevalence of deep periprosthetic infection has been the clinical experience obtained over the past three decades combined with data from several experimental studies (Jiranek et al, 2006). Gentamicin, cefuroxime and tobramycin have been the antimicrobials most commonly admixed into PMMA in clinical studies worldwide (Chiu et al, 2002; Engesaeter et al, 2003; Malchau et al, 1993). In United States, tobramycin has been used most commonly, primarily because the product is available in powdered form. Of the three antibiotics, gentamicin has been used most frequently and studied most extensively overall (Hanssen, 2004).

In a large retrospective study, data on 22170 primary total hip replacements from the Norwegian Arthroplasty Register during the period of 1987 to 2001 were analyzed (Engesaeter et al, 2003). Patients who received only systemic antibiotic prophylaxis had a 1.8 times higher rate of infection than patients who received systemic antibiotic prophylaxis combined with gentamicin-loaded bone cement. Another retrospective study, of 92675 hip arthroplasties listed in the Swedish Joint Registry, presented similar conclusions, with the use of antibiotic-loaded bone cement favored for both primary and revision hip arthroplasties (Malchau et al, 1993).

Recently, prosthesis of antibiotics loaded acrylic bone cement consisting of an acetabular cup filled with antibiotic loaded polymethylmethacrylate bone cement was developed for the treatment of infections at the site of total hip arthroplasty accompanied by the extensive loss of the proximal part of the femur (Younger et al, 1998). The antibiotic usually impregnated is tobramycin or vancomycin with an elution of the former at intraarticular concentrations between 4.35 and $123.88 \mathrm{mg} / \mathrm{L}$ and remains undetected in the latter (Masri et al, 1998). This has resulted in a success rate of $94 \%$ in 61 patients after an average follow-up of 43 months. Polymethylmethacrylate bone cement beads impregnated with vancomycin were successfully used for the treatment of osteomyelitis of the pelvis and of the hip (Ozaki et al, 1998). 
The primary concern regarding antibiotic-loaded acrylic bone cement include the potential for detrimental effects on the mechanical or structural characteristics of polymethylmethacrylate bone cement when antibiotic are admixed. The addition of $>4.5 \mathrm{~g}$ of gentamicin powder per $40 \mathrm{~g}$ package of cement powder or the addition of liquid antibiotics causes a decrease in compressive strength to a level below American Society for Testing and Materials standards (Lautenschlager et al, 1976). The use of high-dose antibiotics in acrylic bone cement spacers ( $>2 \mathrm{~g}$ of antibiotic powder per $40 \mathrm{~g}$ of acrylic bone cement powder) implanted in staged revision procedures can lead to substantial cost savings to the hospital and improvement in patient care. However, the routine use of high-dose antibiotics in cement employed for fixation of prostheses is not supported by evidence (Jiranek et al, 2006).

Another basic concern regarding antibiotic-loaded polymethylmethacrylate bone cement include the potential for development of drug-resistant bacteria. Many of the bacterial pathogens involved in bone and soft tissue infections, particularly Staphylococcus epidermidis, produce a biofilm that limits the activity of antibiotics (Gracia et al, 1998). The biofilm, known as the extracellular slime of glycocalyx, is produced by strains of Staphylococcus aureus and Staphylococcus epidermidis, it also provides these strains with the capacity to adhere the foreign materials, such as the acrylic bone cement beads (Bayston \& Rogers, 1990). Consequently, despite adequate killing of these micro-organisms by invitro elution of antibiotic in close proximity to the beads, the same micro-organisms survive on their surface (Kendall et al, 1996). This stable adherence might provide a mechanism of recurrence of the infection and of development of resistance, since small colony variants of Staphylococcus aureus resistant to gentamicin have been isolated from the wounds of patients with bone and soft tissue infections treated with gentamicin-impregnated acrylic bone cement beads (vonEiff et al, 1997). In a report from the Ohio State University Medical Center, the overall rate of infection decreased with the introduction and use of antibiotic-loaded acrylic bone cement; however, the prevalence of aminoglycosideresistant bacteria, particularly in Staphylococcus aureus and coagulase-negative staphylococcal infections, increased (Wininger \& Fass, 1996). Because of the considerable data suggesting the potential for the development of bacterial antibiotic resistance, antibiotic-loaded polymethylmethacrylate bone cement should not be used routinely for prophylaxis. Rather, it should be used for prophylaxis only when there are clear indications, such as a high-risk primary procedure or a high-risk revision arthroplasty. Vancomycin should not be used as a primary agent for prophylaxis because of the emergence of resistant organisms and the need to reserve this antibiotic for patients who require it for treatment (Hanssen \& Osmon, 1999).

\section{Biodegradable materials}

A variety of bone cement alternatives have been used experimentally and clinically as local antibiotic delivery vehicles and there are many additional products in development. Currently, there are no FDA-approved biodegradable materials available for use to treat established musculoskeletal infection (Nelson, 2004).

Biodegradable implants could provide high local bacteridical concentrations in tissue for the prolonged time needed to completely eradicate the infection and the possibility to match the rate of implant biodegradability according to the type of infection and the possibility to match the rate of implant biodegradability according to the type of infection treated. 
Biodegradation also makes surgical removal of the implant unnecessary. The implant can also be used initially to obliterate the dead space and, eventually, to guide its repair. Furthermore, secondary release of the antibiotic may occur during the degradation phase of the carrier, which could increase antibacterial efficacy compared to non-biodegradable carriers (Nandi et al, 2009).

The biodegradable antibiotic delivery materials have been classified into four broad categories: bone graft and bone substitutes, protein-based materials (natural polymers), synthetic polymers and miscellaneous biodegradable materials (McLaren, 2004). Within these four categories there are several mechanisms of antibiotic release such as the first order kinetics associated with antibiotics attached by surface adsorption and variable antibiotic release rates that are observed with products whereby antibiotics are admixed within the substance of the biomaterial (Hanssen, 2005). In vitro and in vivo elution of antibacterial agents from biodegradable materials are show in tables 4 and 5 .

\begin{tabular}{|l|c|c|c|}
\hline \multicolumn{1}{|c|}{ Study } & Carrier & Antibiotic & $\begin{array}{c}\text { Duration of } \\
\text { release (days) }\end{array}$ \\
\hline Witso et al, 2000 & Bone-graft & Vancomycin & 7 \\
\hline Jia et al, 2010 & Calcium Sulfate & Teicoplanin & 7 \\
\hline $\begin{array}{l}\text { Wachol-Drewek et } \\
\text { al, 1996 }\end{array}$ & Collagen Sponge & Gentamicin & 4 \\
\hline $\begin{array}{l}\text { Tsourvakas et al, } \\
2009\end{array}$ & Fibrin-clot & Ciprofloxacin & 29 \\
\hline Garvin et al, 1994b & Synthetic Polymers & Clindamycin & $38-50$ \\
\hline $\begin{array}{l}\text { Kanellakopoulou et } \\
\text { al, 1999 }\end{array}$ & Polylactate & Tobramycin & $36-75$ \\
\hline & Plaster of Paris & Gentamicin & $38-51$ \\
\hline Mounis et al, 1996 & Polylactate & Fentacin & $51-350$ \\
\hline Shinto et al, 1992 & Fleroxacin & $56-295$ \\
\hline
\end{tabular}

Table 4. Cumulative data from in-vitro studies with antibiotic-loaded in biodegradable materials 


\begin{tabular}{|c|c|c|c|c|}
\hline Study & Carrier & Antibiotic & $\begin{array}{c}\text { Animal } \\
\text { Model }\end{array}$ & $\begin{array}{c}\text { Duration of } \\
\text { release } \\
\text { (days) }\end{array}$ \\
\hline Witso et al, 2000 & Bone-graft & Vancomycin & Rat & 7 \\
\hline & & Ciprofloxacin & & 3 \\
\hline Shinto et al, 1992 & Hydroxyapatite & Gentamicin & Rat & 90 \\
\hline $\begin{array}{c}\text { Stemberger et al, } \\
1997\end{array}$ & Collagen Sponge & Gentamicin & Rabbit & 56 \\
\hline $\begin{array}{c}\text { Tsourvakas et al, } \\
1995\end{array}$ & Fibrin-clot & Ciprofloxacin & Rabbit & 15 \\
\hline $\begin{array}{l}\text { Kanellakopoulou } \\
\text { et al, } 2000\end{array}$ & Lactic-acid & Pefloxacin & Rabbit & 33 \\
\hline Garvin et al, 1994b & $\begin{array}{l}\text { Synthetic } \\
\text { Polymers }\end{array}$ & Gentamicin & Canine & 42 \\
\hline Koort et al, 2008 & $\begin{array}{l}\text { Synthetic } \\
\text { Polymers }\end{array}$ & Ciprofloxacin & Rabbit & 42 \\
\hline
\end{tabular}

Table 5. Cumulative data from in-vivo studies with antibiotic-loaded in biodegradable materials

\subsection{Bone grafts and bone substitutes}

Bone graft, either as autograft or allograft, as a vehicle for local antibiotic delivery, has been used clinically for more than twenty years (McLaren, 2004).

Morselized cancellous bone has been used extensively as bone graft material. There are variations in the material that depend on the method of preparation. The use of morselized cancellous bone as a delivery carrier for antibiotics was developed in 1984 when there was limited choice in bone-grafting material and constraints related to biologic hazards were manageable (McLaren \& Miniaci, 1986). Antibiotics can be added as a powered to morselized cancellous bone or by soaking the bone-graft in an antibiotic-loaded solution. The antibiotic is absorbed directly to the bone surfaces and subsequent release of antibiotics is based on first-order kinetics (McLaren, 2004). Although this clinical application protocols with a variety of different antibiotics, there are very little data regarding the actual concentration levels of the local antibiotics and the clinical effects that this practice has an eventual bone graft incorporation.

In vitro elution studies (McLaren \& Miniaci, 1986) and in vivo studies in a rabbit model (McLaren, 1988) have shown first-order kinetics for release of tobramycin during a period of 
over three weeks. Tobramycin levels exceeded usual bacteridical concentrations for three weeks in the graft material implanted in a rabbit. In another study, the results showed that morselized bone graft can act as a carrier netilmicin, vancomycin, clindamycin and rifampicin in vitro and in vivo. Antibiotics levels exceeded usual bacteridical concentrations for seven days in the graft material implanted in a rat (Witso et al, 2000).

Application of antibiotic impregnated autogenic cancellous bone grafting has already been introduced in clinical practice. Chan et al, in 1998, reported results from 36 patients with infected fractures resulting from traffic accidents. After surgical debridement an iliac cancellous bone graft was taken and mixed by the surgeon with piperacillin and/or vancomycin, depending on the susceptibility of the isolated infective micro-organism. The graft was then implanted at the site of infection inside the osseous defect, which occurred principally in the proximal, middle or distal segment of the left or right tibia. Four to five months were necessary for bone union, and the only complications presented were skin rashes.

Impregnation of antimicrobial agents within osteoconductive biomaterials (calcium sulfate, calcium phosphate, hydroxyapatite or tricalcium phosphate) has been proposed for local treatment of osteomyelitis and to aid dead space management (Kawanabe et al, 1998; Makinen et al, 2005; Nelson et al, 2005). As a common feature, these implants show a rapid release of the antibiotic in a more or less controlled manner (McLaren, 2004). One of the benefits of this class of materials is that implantation provides the opportunity to deliver local antibiotics at high concentrations and simultaneously participate in the bone regeneration process during the time period of material degradation. These materials also avoid the risk of transmitting disease pathogens associated with the use of allograft bone.

Of these materials, commercial calcium sulfate has probably been used most commonly in the clinical setting of osteomyelitis treatment (Gitelis \& Brebach, 2002). The most appropriate antibiotic dosage regimen not clear however, the most common formulation used clinically has been $3.64 \%$ vancomycin or $4.25 \%$ tobramycin per weight (Gitelis \& Brebach, 2002). These percentages equate to $1 \mathrm{~g}$ of vancomycin or $1.2 \mathrm{~g}$ for tobramycin per $25 \mathrm{~g}$ of calcium sulfate. Other antibiotic-loaded biomaterials being investigated in this category include calcium hydroxyapatites (Shirliff et al, 2002), calcium phosphates (Lazarettos et al, 2004), bioactive glasses (Kawanabe et al, 1998) and antibiotic loaded blood coated demineralized bone (Rhyu et al, 2003).

\subsection{Natural polymers (protein-based materials)}

This category includes antibiotic-loaded sponge collagen (Mehta et al, 1996; Ruszcak \& Friess, 2003), fibrin (Tredwell et al, 2005; Tsourvakas et al, 1995), thrombin, and other commercially available systems that use clotted blood products. Although there are investigators actively involved in the use of these materials, their use as local antibiotic delivery vehicles is not as common as the use of antibiotic-loaded bone cement, antibioticloaded bone graft substitutes in the treatment of bone and soft tissue infections.

These materials function as delivery vehicles by providing a physical scaffold around the antibiotic mechanically limiting fluid flow, or by providing a protein to bind the antibiotic. Some data on release properties are published for all of these materials determined by either elution studies or by animal studies. Elution rates, tend to be rapid, leading to release of 
essentially all of the contained antibiotic in the range of hours to a few days. Antibiotic release in animal models is slower. Time to release the majority of contained antibiotic ranges from many days to several weeks. The investigations generating these data are limited, using a wide spectrum of methods, making a comparison of performance of these materials invalid. Clinical guidelines for the amount of the material to be used and for the dose of the contained antibiotic are not possible (McLaren, 2004).

Collagen sponge is the material in this group that was the best supporting data. It is a solid mesh of collagen-based spongy material, produced from sterile animal skin or tendo Achillis. Since collagen is a major component of connective tissue and the main structural protein of all organs, it has several desirable biological properties, including both biocompatibility and non-toxicity. Its ability to release drugs can be modified by changing the porosity of the matrix or by treating it with chemicals (Rao, 1995). It can also attract and stimulate the proliferation of osteoblasts, thereby promoting mineralization and the production of collagenous callus tissue, which aids the formation of new bone (Reddi, 1985).

Collagen sheets with impregnated gentamicin have been used to treat chronic osteomyelitis (Ipsen et al, 1991). It has been commercially available in Europe for ten years and is produced from sterilized bovine tendon in which gentamicin is suspended. In vitro studies of antibiotic release from collagen sponges showed four days to complete (Wachol-Drewek et al, 1996). When collagen sponge is combined with liposome encapsulated antibiotics, the duration of time for release of the antibiotics has been reported to be up to three times greater that that of collagen sponge alone (Trafny et al, 1996). Polymyxin-B and amikacin have been shown in other laboratory experiments to have significant sustained release action against Pseudomonas aeruginosa when attached to type I collagen (Trafny et al, 1995). Gentamicin impregnated collagen sponge shows up to 600 times MIC as compared to polymethylmethacrylate beads at 300 times MIC .It has also been observed that due to its release of large amounts of gentamicin the flexible gentamicin-contained collagen sponge proved to be superior to the rigid polymethylmethacrylate beads. Other authors conclude that it is an effective delivery vehicle for up to 28 days in a rabbit model (Humphrey et al, 1998) and that it is effective clinically (Kanellakopoulou \& Giamarellos-Bourboulis, 2000). Further characterization and technique refinement are required before it can be recommended as a delivery vehicle for antibiotics. Commercially prepared antibiotic-laden collagen sponge is not available for use in the United States.

Fibrin sealants are topical hemostatic materials derived from plasma coagulation proteins that are being used increasingly in surgical procedures (Jackson, 2001). Fibrin sealants have great potential for the delivery of antibiotics, chemotherapy, and even growth factors at surgical sites (Jackson, 2001). They are biocompatible and degrade by normal fibrinolysis within days or weeks depending on the site. The main use of fibrin sealants has been in cardiovascular, thoracic, dental, plastic and reconstructive surgery. More recently, orthopedic procedures, such as total knee arthroplasty or hip replacement, have also been shown to benefit from the use of fibrin sealants (Jackson, 2001).

Clearly, the compatibility of these materials with surgical wound sites makes fibrin sealant logical candidates for use as controlled-release carriers for local antibiotic delivery. It has been shown that antibiotics with low water solubility, such as tetracycline base, are particularly suited to this system (Woolveron et al, 2001), presumably because the precipitated drug 
dissolves and diffuses slowly from the fibrin clot. Even more water-soluble antibiotics such as gentamicin and ciprofloxacin have been shown to release in vitro from fibrin over 5-7 days for gentamicin (Kram et al, 1991) and over 60 days for ciprofloxacin (Tsourvakas et al, 1995), although more than $66 \%$ was released in the first two days. In an animal model the maximum level of ciprofloxacin in bone and soft tissues, after the implantation of composite in the medullary canal of rabbit tibia, was obtained on the second day after implantation, and the drug was undetectable after ten days (Tsourvakas et al, 1995).

Zilch and Lambiris (1986) measured the cefotaxime concentrations in both blood and wound drainage from 46 patients with osteomyelitis who were treated with a fibrin clot cefotaxime mixture injected into the bone cavity. These authors reported serum levels that were low within 12 hours after fibrin clot placement, but wound drainage fluid maintained high concentrations for more than 3 days.

Fibrin clot antibiotic mixtures are a promising approach to providing a biocompatible tissue sealant with local antibiotic release that may decrease the incidence of postoperative infections. Further in vitro work is necessary to characterize the effect the addition of antibiotics has on the rate and strength of fibrin clotting. Additional in vivo data are necessary to determine what effect low systemic levels of antibiotics might have on antibiotic resistance patterns.

\subsection{Synthetic polymers}

Although collagen sponge is an established method of managing infection, there is great interest in developing a carrier with longer lasting effects and better penetration. Biodegradable synthetic polymers have been used in surgery since the 1950s as suture material. Advances in processing have generated stronger, more reliable synthetic polymers based implants for consideration as carriers (El-Husseiny et al, 2011).

The most active area of current research using biodegradable polymers from glycolide and lactide is in the controlled delivery of drugs especially in antibiotics such as ampicillin, gentamicin, polymyxin B and quinolones (Calhoun \& Mader, 1997; Kanellakopoulou et al, 1994; Nie et al, 1995). Polylactide/polyglycolide was selected to act as a carrier because it undergoes a gradual degradation in a controlled manner and dissolves at physiological $\mathrm{pH}$ and removal is thus not necessary in patients who have bone and soft tissue infections (Nandi et al, 2009). A second advantage is that the kinetics of the release of the antibiotic can be modified by the selection of copolymers of varying monometric composition, polymer crystallinity and molecular weight as well as by alteration of the geometry of the implant. Finally, preliminary studies indicated that these materials is highly compatible with a wide variety of antibiotics and the in vivo release of antibiotics occurs for a definite time period with therapeutic concentrations, which may minimize slow residual release at suboptimal concentrations (Makinen et al, 2005).

Polymers are available in different patterns such as polylactides, copolymers of lactide and glycolide, polyanhydride and polycarpolactone. Copolymers of polylactides and polyglycolic acid have been produced with a ratio between the two composites varying between 90:10 and 50:50. It has been observed from in vitro studies that the 90:10 ratio provides better stability, delayed decomposition and superior elution concentrations of 
tobramycin, clindamycin and vancomycin than copolymers produced at other ratios (Bunetel et al, 1990). Copolymers (50:50)-gentamicin implant was significantly more successful than the use of the standard parenteral therapy in experimental osteomyelitis in canine model (Garvin et al, 1994).

The biocompatibility of polylactide/polyglycolide acid has been well established. The tissue reaction to implanted materials is minimum, with the inflammatory response limited to a narrow region, which gradually diminishes as the polymer is desorbed (Brady et al, 1973).

Although lactide/glycolide polymers were suggested as carriers for antibiotics thirty years ago (Thies, 1982), it was ten years before linked lactic acid chains were proposed as a drug delivery system for the treatment of bone and soft tissue infections. Wei et al in 1991 implanted molded rods, made by heating a mixture of lactic acid oligomer and dideoxykanamycin B, into rabbit models. They showed that the MIC of antibiotic for the common causative organisms of osteomyelitis was exceeded for six weeks in the cortex, the cancellous bone, and in the bone marrow. Furthermore, the majority of the implant material has been absorbed, and the bone marrow had returned to a nearly normal state within nine weeks of implantation.

Sampath et al in 1992 demonstrated an alternative method of delivering gentamicin locally using polymers. They prepared microcapsules composed of a polylactic acid shell containing gentamicin which was then compressed into the desired shape. It was noted that more $80 \%$ of antibiotic was released in the first three weeks in vitro. The efficacy of microcapsules in osteomyelitis has also been demonstrated in a study by Garvin et al, in 1994.

The polylactate polymers achieve prolonged in vivo quinolones release at higher levels than the other systems and produced their peal drug release after 15 days (Kanellakopoulou et al, 1994). On the basis of the adequacy of elution of quinolones from the polylactate carrier, pefloxacin impregnated of this carrier was used for therapy of an experimental osteomyelitis caused by the local application of MRSA in rabbits (Kanellakopoulou et al, 2000).

One of the primary drawbacks with synthetic polymers has been the difficulties associated with designing implants that also providing structural integrity. For this specific reason, the use of this category of biomaterials, like the other non-cement alternatives, has primarily been for the treatment of osteomyelitis. Although the structural requirements necessary for other applications can be accomplished for these implants initially, the process of polymer degradation often has led to severe loss of structural integrity during the course of treatment (Hanssen, 2005).

Synthetic polymers could function as a delivery vehicle for antibiotics with further evaluation and development. Manipulation of the material properties and combinations of one or more of these material can lead to any clinically desirable release rate. Investigations have been exploring these variables (Ambrose et al, 2003). However, no one material has shown dominance with confirmatory investigations and progression in development towards a usable clinical preparation. There are not available for clinical use as a depot antibiotic delivery vehicle. This may be related in part to the economics of bringing these products to market premixed with antibiotic. Currently, there is no polymer available that can be hand mixed with antibiotics in the operating room. 


\subsection{Miscellaneous}

The range of different intended functions of these materials include different rates and timing of antibiotic release, provision of physicochemical characteristics necessary for osteoconduction, and provision of a scaffold that allows osteoconduction, osseous integration, and sufficient structural properties.

Antibiotic loaded plaster of Paris pellets is an effective ancillary treatment in the surgery of infected cavities in bone. It is well tolerated and spontaneous absorbed over a period of weeks to months, being replaced by bone if normal architecture (Mackey et al, 1982). Many antibiotics can be added to plaster of Paris, such as gentamicin, fucidic acid, and teicoplanin (Dacquet et al, 1992; Mackey et al, 1982).

Fibres locally releasing tetracycline hydrochloride have been successfully introduced for the therapy of persistent or recurrent periodontitis (Tonetti et al, 1998). Chitosan is an excellent biomaterial with biodegradable and immunologic activity, the gentamicin loaded chitosan bar seems to be a clinically useful method for the treatment of bone and soft tissue infections (Aimin et al, 1999). Different types of gel like hyalouronic acid (Matsuno et al, 2006), fibrin gel with bone marrow derived mesenchymal stem cells (Hou et al, 2008), and monoolein-water gels (Ouedraogo et al, 2008) have been used as an alternative treatment for bone and soft tissue infections.

Some unconventional marine biomaterials like sponge skeleton, coral, snail slime with varied intraglanular porosity are future promising options as bone grafts substitute. Most of the commonly used and under trial bone graft substitutes only have osteoconductive and osteogenic characters. Therefore, it is of paramount necessity to develop an ideal novel smart biomaterials with all three properties which cannot only provide sufficient concentration of antibiotic at the target site but also act as a bone strut to accelerate the goal. This may be achieved by combining conventional and some unconventional growth factors with the carrier materials including the incorporation of stem cells (Nandi et al, 2009).

The necessary data on the efficacy of these new biodegradable materials still are in early stages of development and assessment. Despite the vast potential to develop composite biomaterials that can provide multiple functions, the complexity of the cellular and molecular interactions within the wound environment exposes the potential for unforeseen adverse consequences. In fact, many of the clinical scenarios of treatment of musculoskeletal infection include the need for local antibiotics and stimulation of the process of bone regeneration. One of the most obvious adverse effects of high level of local antibiotics is an osteoblast function and subsequent bone regeneration. The concern is valid for specific clinical situations such as antibiotic bead pouches for treatment of open fractures (Henry et al, 1993b), bone grafting for nonunions, and implantation of devices into bone defects where bone regeneration is an intended outcome of the deadspace management strategy (Gitelis \& Brebach, 2002).

\section{Conclusion}

The appropriate use of antimicrobial agents has decreased morbidity and mortality from orthopedic-related infections. Although systemic antibiotic use has been used for many years, new methods of local antibiotic delivery may result in increased antibiotic levels, decreased toxicity, and possibly greater efficacy. Antibiotic impregnated polymethylmethacrylate beads 
are currently being used in a variety of applications, but this method require a second procedure for removal of the antibiotic delivery system.

There is considerable interest in finding methods of delivering effective doses of antimicrobial drugs locally, not only in orthopedics, but across a range of specialists. While most of the antibacterial agent contained within a biodegradable system may be eluted, only $25 \%$ is actually released from polymethylmethacrylate beads. Biodegradable materials could mimic bone substances like calcium phosphate based carriers can be chosen for local drug delivery system in osteomyelitis with potential clinical application in orthopedic surgery. Widespread research is currently being conducted in the area of local drug delivery systems to treat osteomyelitis. Despite this fact, much work is still desired in the areas of biodegradable and biocompatible materials, the kinetics of antibiotic release, and further development of current systems before many of these formulations can be used. The seer diversity of available systems and the lack of suitable trials comparing them in-vivo makes their evaluation difficult. Nonetheless, it is apparent that while collagen fleece is currently the most widely used antimicrobial carrier system, the duration of its antibiotic delivery is the shortest. Other delivery systems have shown greater promise, and these that are able both to stimulate the formation of new bone and provide a scaffold, such as composite antibiotic carriers, are most likely to gain widespread acceptance in the future.

In future, researchers remain optimistic that many of these systems can be developed with ideal zero-order release kinetics profiles, in-vivo, over long periods of time, allowing for widespread use in chronic osteomyelitis patients. By utilizing newer forms of sustainedrelease antibiotic delivery systems, it will be possible to deliver such antibiotics at constant rates over a prolonged period of time and would eliminate the need for multiple dosing. It is hoped that in the future, development of new implantable systems would be helpful to reduce the cost of drug therapy, increase the efficacy of drugs, and could enhance the patient's compliance.

\section{References}

Adams K., Couch L., Cierny G., Calhoun J., \& Mader JT. (1992). In vitro and in vivo evaluation of antibiotic diffusion from antibiotic-impregnated polymethylmethacrylates beads. Clinical Orthopaedics Related Research, Vol. 278, (May 1992), pp. 244-252, ISSN 0009921X

Aimin C., Chunlin H., Juliang B., Tinyin Z., \& Zhichao D. (1999). Antibiotic loaded chitosan bar. An in-vitro, in-vivo study of a possible treatment of osteomyelitis. Clinical Orthopaedics Related Research, Vol. 366, (September 1999), pp. 239-247, ISSN 0009921X

Allababidi S., \& Shah JC. (1998). Kinetics and mechanism of release from glyceryl monostearate-based implants: evaluation of release in a gel stimulating in vivo implantation. Journal Pharmaceutical Sciences, Vol. 87, No 6, (June 1998), pp. 738-744, ISSN 0022-3549

Alonge TO., \& Fashing AN. (2000). Ceftriaxone-PMMA beads - a slow release preparation? International Journal Clinical Practice, Vol. 54, No 6, (July 2000), pp. 353-355, ISSN 1368-5031 
Baker AS., \& Greenham LW. (1988). Release of gentamicin from acrylic bone cement. Elution and diffusion studies. Journal Bone Joint Surgery, Vol. 70-A, No 10, (December 1988), pp. 1551-1557, ISSN 0021-9355

Bayston R., \& Rodgers J. (1990). Production of extra-cellular slime by Staphylococcus epidermis during stationary phase of growth: its association with adherence to implantable devices. Journal Clinical Pathology, Vol. 43, No 10, (October 1990), pp. 866-870, ISSN 0021-9746

Brady IM., Cutright DE., Miller RA., \& Barristance GC. (1973). Resorption rate, route, route of elimination, and ultrastructure of the implant site of polylactic acid in the abdominal wall of the rat. Journal Biomedical Materials Research, Vol. 7, No 2, (March 1973), pp. 155-166, ISSN 0021-9304

Brien WW., Salvati EA., Brause B., \& Stern S. (1993). Antibiotic impregnated bone cement in total hip arthroplasty. An in-vivo comparison of the elution properties of tobramycin and vancomycin. Clinical Orthopaedics Related Research, Vol. 296, (November 1993), pp.242-248, ISSN 0009-921X

Buchholz HW., \& Engelbrecht H. (1970). Uber die depotwirkung einiger antibiotica bei vermischung mit dem kunstharz Palacos. Chirurg, Vol. 41, No 11, (November 1970), pp. 511-515, ISSN 0009-4722

Buchholz HW., Elson RA., \& Heinert K. (1984). Antibiotic-loaded acrylic cement: current concepts. Clinical Orthopaedics Related Research, Vol. 190, (November 1984), pp. 96108, ISSN 0009-921X

Bunetel L., Sequi A., Cormier M., \& Langlais F. (1990). Comparative study of gentamicin release from normal and low viscosity acrylic bone cement. Clinical Pharmacokinetic, Vol. 19, No 4, (October 1990), pp. 333-340, ISSN 0312-5963

Calhoun JH., \& Mader JT. (1989). Antibiotic beads in the management of surgical infections. American Journal Surgery, Vol. 157, No 4, (April 1989), pp. 443-449, ISSN 0002-9610

Calhoun JH., \& Mader JT. (1997). Treatment of osteomyelitis with a biodegradable antibiotic implant. Clinical Orthopaedics Related Research, Vol. 341, (August 1997), pp. 206-214, ISSN 0009-921X

Cevher E., Orhan Z., Mulazimoglu L., Sensoy D., Alper M., Yildiz A., \& Ozsoy Y. (2006). Characterization of biodegradable chitosan microspheres containing vancomycin and treatment of experimental osteomyelitis caused by methicillin-resistant staphylococcus aureus with prepared microspheres. International Journal Pharmaceutics, Vol. 317, No 2, (July 2006), pp. 127-135, ISSN 0378-5173

Chan YS., Ueng SW., Wang CJ., Lee SS., Chao EK. ,\& Shin CH. (1998). Management of small infected tibial defects with antibiotic-impregnated autogenous cancellous bone grafting. Journal of Trauma, Vol. a5, No 4, (October 1998), pp. 758-764, ISSN 00225282

Chiu FY., Chen CM., Lin CF., \& Lo WH. (2002). Cefuroxime-impregnated cement in primary total knee arthroplasty: a prospective randomized study of three hundred and forty knees. Journal Bone Joint Surgery, Vol. 84-A, No 5, (May 2002), pp. 759-762, ISSN 0021-9355

Cho SH., Song HR., Koo KH., Jeong ST., \& Park YJ. (1997). Antibiotic-impregnated cement beads in the treatment of chronic osteomyelitis. Bulletin Hospital Joint Diseases, Vol. 56, No 3, (March 1997), pp. 140-144, ISSN 0018-5647 
Chohfi M., Langlais F., Fourastier J., Minet J., Thomazeau H., \& Cormic M. (1998). Pharmacokinetics, uses, and limitations of vancomycin-load bone cement. International Orthopaedics, Vol. 22, No 3, (April 1998), pp. 171-177, ISSN 0341-2695

Cierny G., \& Mader JT. (1987). Approach to adult osteomyelitis. Orthopaedic Review, Vol. 16, No 4, (April 1987), pp. 259-270, ISSN 0094-6591

Cierny III G. (1999). Infected tibial nonunions (1989-1995). The evolution of change. Clinical Orthopaedics Related Research, Vol. 360, (March 1999), pp. 97-105, ISSN 0009-921X

Dacquet V., Varlet A., Tandogan RN., Tation MM., Fournier L., Jehl F., Monteil H., \& Bascoulergue G. (1992). Antibiotic-impregnated plaster of Paris beads. Trials with teicoplanin. Clinical Orthopaedics Related Research, Vol. 282, (September 1992), pp. 241-249, ISSN 0009-921X

Dombrowski ET., \& Dunn AW. (1965). Treatment of osteomyelitis by debridement and closed wound irrigation-suction. Clinical Orthopaedics Related Research, Vol.43, (September 1965), pp. 215-231, ISSN 0009-921X

Dounis E., Korakis T., Anastasiadis A., Kanellakopoulou K., Andreopoulos A., \& Giamarellou H. (1996). Sustained release of fleroxacin in vitro from lactic acid polymer. Bulletin Hospital Joint Disease, Vol. 55, No 1, (January 1996), pp. 16-19, ISSN 0018-5647

El-Husseini M., Patel S., MacFarlane RJ., \& Haddad FS. (2011). Biodegradable antibiotic delivery systems. Journal Bone Joint Surgery, Vol. 93-B, No 2, (February 2011), pp. 151-157, ISSN 0301-620X

Engesaeter LB., Lie SA., Espehaug B., Furnes O., Vollset SE., \& Havelin LI. (2003). Antibiotic prophylaxis in total hip arthroplasty: effects of antibiotic prophylaxis systemically and in bone cement on the revision rate of 22170 primary hip replacements followed 0-14 years in the Norwegian Arthroplasty Register. Acta Orthopaedica Scandinavica, Vol. 74, No 6, (December 2003), pp. 644-651, ISSN 0001-6470

Fleming A. (1920). The action of chemical and physiological antiseptics in a septic wound. British Journal Surgery, Vol. 7, pp. 99-129

Fux CA., Costerton JW., Stewart PS., \& Stoodley P. (2005). Survival strategies of infections biofilm. Trends Microbiology, Vol. 13, No 1, (January 2005), pp. 34-40, ISSN 0966$842 X$

Galanakis N., Giamarellou H., Moussas T., \& Dounis E. (1997). Chronic osteomyelitis caused by multi-resistant Gram-negative bacteria: evaluation of treatment with newer quinolones after prolonged follow-up. Journal Antimicrobial Chemotherapy, Vol. 39, No 2, (February 1997), pp. 241-246, ISSN 0305-7453

Carvin KL., Evans BG., Salvati EA., \& Brause BD. (1994a). Palacos gentamicin for the treatment of deep periprosthetic hip infections. Clinical Orthopaedics Related Research, Vol. 298, (January 1994), pp. 97-105, ISSN 0009-921X

Garvin KL., Miyono JA., Robinson D., Giger D., Novak J., \& Radio S. (1994b). Polylactide/polyglycolide antibiotic implants in the treatment of osteomyelitis. A canine model. Journal Bone Joint Surgery, Vol. 76-A, No 10, (October 1994), pp. 1500 1506, ISSN 0021-9355

Gitelis S., \& Brebach GT. (2002). The treatment of chronic osteomyelitis with a biodegradable antibiotic-impregnated implant. Journal Orthopaedic Surgery (Hong-Kong), Vol. 10, No 1, (June 2002), pp. 53-60, ISSN 1022-5536 
Gracia E., Lacteriga A., Monzon M., Leiva J., Oteiza C., \& Amorena B. (1998). Application of a rat osteomyelitis model to compare in vivo and in vitro the antibiotic efficacy against bacteria with high capacity to form biofilms. Journal Surgical Research, Vol. 79, No 2, (October 1998), pp. 146-153, ISSN 0022-4804

Greene N., Holtom PD., Warren CA., Shepherd L., McPherson EJ., \& Patzakis MJ. (1998). In vitro elution of tobramycin and vancomycin polymethylmethacrylate beads and spacers from Simplex and Palacos. American Journal Orthopaedics, Vol. 27, No 3, (March 1998), pp. 201-205, ISSN 1078-4519

Gursel I., Korkusuz F., Turesin F., Alaeddinoglu NG., \& Hasirci V. (2001). In vivo application of biodegradable controlled antibiotic release system for the treatment of implant-related osteomyelitis. Biomaterials, Vol. 22, No 1, (January 2001), pp. 7380, ISSN 0142-9612

Haddad FS., Muirhead-Allwood SK., Manktelow AR., \& Bacarese-Hamilton I. (2000). Two stage uncemented revision hip arthroplasty for infection. Journal Bone Joint Surgery, Vol. 82-b, No 5, (July 2000), pp. 689-694, ISSN 0301-620X

Hanssen AD., Rand JA., \& Osmon DR. (1994). Treatment of the infected total knee arthroplasty with insertion of another prosthesis. The effect of antibioticimpregnated bone cement. Clinical Orthopaedics Related Research, Vol. 309, (December 1994), pp. 44-55, ISSN 0009-921X

Hanssen AD., \& Osmon DR. (1999). The use of prophylactic antimicrobial agents during and after hip arthroplasty. Clinical Orthopaedics Related Research, Vol. 369, (December 19999), pp. 124-138, ISSN 0009-921X

Hanssen AD. (2004). Prophylactic use of antibiotic bone cement: an emerging standard-in opposition. Journal of Arthroplasty, Vol. 19, No 4, (June 2004), pp. 759-762, ISSN 0883-5403

Hanssen AD. (2005). Local antibiotic delivery vehicles in the treatment of musculoskeletal infection Clinical Orthopaedics Related Research, Vol. 437, (August 2005), pp. 91-96, ISSN 0009-921X

Hanssen AD., Osmon DR., \& Patel R. (2005). Local antibiotic delivery systems: what are and where are we going? Clinical Orthopaedics Related Research, Vol. 437, (August 2005), pp. 111-114, ISSN 0009-921X

Henry SL., Seligson D., Mangino P., \& Popham GJ. (1991). Antibiotic-impregnated beads. Part I: bead implantation versus systemic therapy. Orthopaedic Review, Vol. 20, No 3, (March 1991), pp. 242-247, ISSN 0094-6591

Henry SL., Hood GA., \& Seligson D. (1993). Long term implantation of gentamicinpolymethylmethacrylate antibiotic beads. Clinical Orthopaedics Related Research, Vol. 295, (October 1993), pp. 47-53, ISSN 0009-921X

Henry SL., Ostermann PA., \& Seligson D. (1993). The antibiotic bead pouch technique. The management of severe compound fractures. Clinical Orthopaedics Related Research, Vol. 295, (October 1993), pp. 54-62, ISSN 0009-921X

Henry SL., \& Galloway KP. (1995) local antibiotic therapy for the management of orthopaedic infections. Pharmacokinetic considerations. Clinical Pharmacokinetics, Vol. 29, No 1, (July 1995), pp. 36-45, ISSN 0312-5963

Hoff SF., Fitzgerald RH Jr., \& Kelly PJ. (1981). The depot administration of penicillin G and gentamicin in acrylic bone cement. Journal Bone Joint Surgery, Vol. 63-A, No 5, (June 1981), pp. 798-804, ISSN 0021-9355 
Holtom PD., Warren CA., Greene NW., Bravos PD., Ressler RL., Shepherd L., McPherson EJ., \& Patzakis MJ. (1998). Relation of surface area to in vitro elution characteristics of vancomycin-impregnated polymethylmethacrylate spacers. American Journal Orthopaedics, Vol. 27, No 3, (March 1998), pp. 207-210, ISSN 1078-4519

Hou T., Xu J., Li Q., Feng J., \& Zen L. (2008). In vitro evaluation of a fibrin gel antibiotic delivery system containing mesenchymal stem cells and vancomycin alginate beads for treating bone infections and facilitating bone formation. Tissue Engineering Part A, Vol. 14, No 7, (July 2008), pp. 1173-1182, ISSN 2152-4947

Humphrey JS., Mehta S., Seober AV., \& Vail TP. (1998). Pharmacokinetics of a degradable drug delivery system in bone. Clinical Orthopaedics Related Research, Vol. 349, (April 1998), pp. 218-224, ISSN 0009-921X

Ipsen T., Jorgensen PS., Damholt V., \& Torholm C. (1991). Gentamicin-collagen sponge for local applications. 10 cases of chronic osteomyelitis followed for 1 year. Acta Orthopaedica Scandinavica, Vol. 62, No 6, (December 1991), pp. 592-594, ISSN 0001-6470

Izquierdo RJ., \& Northmore-Ball MD. (1994). Long term results of revision hip arthroplasty. Survival analysis with special reference to the femoral component. Journal Bone Joint Surgery, Vol. 76-B, No 1 (January 1994), pp. 34-39, ISSN 0301-620X

Jackson MR. (2001). Fibrin sealants in surgical practice: An overview. American Journal Surgery, Vol. 182, No 2 Suppl., (August 2001), pp. 1-7, ISSN 0002-9610

Jenny G. (1988). Local antibiotic therapy using gentamicin-PMMA chains in post-traumatic bone infections. Sort and long-term results. Reconstruction Surgery Traumatology, Vol. 157, No 4, (March 1988), pp. 36-46, ISSN 0080-0260

Jensen NK., Johnsrud LW., \& Nelson MC. (1939). The local implantation of sulfonamide in compound fractures. Surgery, Vol. 6, pp. 1-12

Jia WY., Luo SH., Zhang CQ., \& Wang JQ. (2010). In vitro and in vivo efficacies of teicoplanin-loaded calcium sulfate of chronic methicillin-resistant Staphylococcus aureus osteomyelitis. Antimicrobial Agents Chemotherapy, Vol. 54, No 1, (January 2010), pp. 170-176, ISSN 0066-4804

Jiranek WA., Hanssen AD., \& Greenwald AS. (2006). Antibiotic-loaded bone cement for infection prophylaxis in total joint replacement. Journal Bone Joint Surgery, Vol. 88A, No 11, (November 2006), pp. 2487-2500, ISSN 0021-9355

Josafsson G., Gudmudsson G., Kolmert L., \& Wijkstrom S. (1990). Prophylaxis with systemic antibiotics versus gentamicin bone cement in total hip arthroplasty. A five-year survey of 1688 hips. Clinical Orthopaedics Related Research, Vol. 253, (April 1990), pp. 173-178, ISSN 0009-921X

Kanellakopoulou K., Tsourvakas S., Korakis T., Andreopoulos A., Dounis E., \& Giamarellou H. (1994). The release of pefloxacin from acrylic bone cement and lactic-acid polymer. A comparative in vitro study. Proceeding of $5^{\text {th }}$ International Symposium on New Quinolones, Singapore, August 1994

Kanellakopoulou K., Kolia M., Anastasiadis A., Korakis T., Giamarellos-Bourboulis EJ., Andreopoulos A., Dounis E., \& Giamarellou H. (1999). Lactic-acid polymers as biodegradable carriers of fluoroquinolones: an in vitro study. Antimicrobial Agents Chemotherapy, Vol. 43, No 3, (March 1999), pp. 714-716, ISSN 1532-0227

Kanellakopoulou K., \& Giamarellos-Bourboulis EJ. (2000). Carrier systems for the local delivery of antibiotics in bone infections. Drugs, Vol. 59, No 6, (June 2000), pp. 1223132, ISSN 0012-6667 
Kanellakopoulou K., Galanakis N., Giamarellos-Bourboulis EJ., Rifiotis C., Papakostas K., Andreopoulos A., Dounis E., Karagiannakos P., \& Giamarellou H. (2000). Treatment of experimental osteomyelitis caused by methicillin-resistant Staphylococcus aureus with a biodegradable system of lactic acid polymer releasing pefloxacin. Journal Antimicrobial Chemotherapy, Vol. 46, No 2, (August 2000), pp. 311-314, ISSN 0365-7453

Kawanabe K., Okada Y., Matsusue Y., Iida H., \& Nakamura T. (1998). Treatment of osteomyelitis with antibiotic-soaked porous glass ceramic. Journal Bone Joint Surgery, Vol. 80-B, No 3, (May 1998), pp. 527-530, ISSN 0301-620X

Kendall RW., Duncan CP., Smith JA., \& Nqui-Yen JH. (1996). Persistence of bacteria on antibiotic loaded acrylic depots. A reason of caution. Clinical Orthopaedics Related Research, Vol. 329, (August 1996), pp. 273-280, ISSN 0009-921X

Klemm K. (2001). The use of antibiotic-containing bead chains in the treatment of chronic bone infections. Clinical Microbiology Infection, Vol. 7, No 1, (January 2001), pp. 2831, ISSN 1198-743X

Kobayasi H., Shiraki K., \& Ikada Y. (1992). Toxicity test of biodegradable polymers by implantation in rabbit cornea. Journal Biomedical Materials Research, Vol. 26, No 11, (November 1992), pp. 1463-1476, ISSN 0021-9304

Koort JK., Makinen TJ., Suokas E., Veiranto M., Jalava J., Tormala P., \& Aro HT. (2008). Sustained release of ciprofloxacin from an osteoconductive poly(DL)-lactide implant. Acta Orthopaedica, Vol. 79, No 2, (April 2008), pp. 295-301, ISSN 1745-3674

Kram HB., Bansal M., Timberlake O., \& Shoemaker WC. (1991). Antibacterial effects of fibrin glue-antibiotic mixtures. Journal Surgical Research, Vol. 50, No 2, (February 1991), pp. 175-178, ISSN 0022-4804

Kuechle DK., Landon GC., Musher DM., \& Noble PC. (1991). Elution of vancomycin, daptomycin, and amikacin from acrylic bone cement. Clinical Orthopaedics Related Research, Vol. 264, (March 1991), pp. 302-308, ISSN 0009-921X

Lautenschlager EP., Jacobs JJ., Marshal GW., \& Meyer PRJr. (1976). Mechanical properties of bone cements containing large doses of antibiotic powders. Journal Biomedical Materials Research, Vol. 10, No 6, (November 1976), pp.929-938, ISSN 0021-9304

Lazarettos J., Efstathopoulos N., Papagelopoulos PJ., Savidou OD., Kanellakopoulou K., Giamarellou H., Giamarellos- Bourboulis EJ., Nikolaou V., Kapranou A., Papalois A., \& Papachristou G. (2004). A bioresorbable calcium phosphate delivery system with teicoplanin for treating MRSA osteomyelitis. Clinical Orthopaedics Related Research, Vol. 423, (June 2004), pp. 253-258, ISSN 0009-921X

Lazzarini L., Mader TT., \& Calhoun JH. (2004). Osteomyelitis in long bones. Journal Bone Joint Surgery, Vol. 86-A. No 10, (October 2004), pp. 2305-2318, ISSN 0021-9355

Li XD., \& Hu YY. (2001). The treatment of osteomyelitis with gentamicin-reconstituted bone xenograft-composite. Journal Bone Joint Surgery, Vol. 83-B, No 7, (September 2001), pp. 1063-1068, ISSN 0301-620X

Mackey D., Varlet A., \& Debeaumant D. (1982). Antibiotic loaded plaster of Paris pallet: an in vitro study of a possible treatment of osteomyelitis. Clinical Orthopaedics Related Research, Vol. 366, (July 1982), pp. 263-268, ISSN 0009-921X

Mader JT., Landon GC., \& Calhoun J. (1993). Antimicrobial treatment of osteomyelitis. Clinical Orthopaedics Related Research, Vol. 295, (October 1993), pp87-95, ISSN 0009921X 
Mader JT., Calhoun J., \& Cobos J. (1997). In vitro evaluation of antibiotic diffusion from antibiotic-impregnated biodegradable beads and polymethylmethacrylate beads. Antimicrobial Agents Chemotherapy, Vol. 41, No 2, (February 1997), pp. 415-418, ISSN 0066-4804

Makinen JT., Veiranto M., Lankinen P., Moritz N., Jalava J., Tormala P., \& Aro HT. (2005). In vitro and in vivo release of ciprofloxacin from osteoconductive bone defect filler. Journal Antimicrobial Chemotherapy, Vol. 56, No 6, (December 2005), pp. 1063-1068, ISSN 0305-7453

Malchau H., Herberts P., \& Ahnfelt L. (1993). Prognosis of total hip replacement in Sweden. Follow up of 92675 operations performed 1978-1990. Acta Orthopaedica Scandinavica, Vol. 64, No 5, (October 1993), pp. 497-506, ISSN 0001-6470

Marks KE., Nelson CL., \& Lautenschlager EP. (1976). Antibiotic-impregnated acrylic bone cement. Journal Bone Joint Surgery, Vol. 58-A, No 3, (April 1976), pp., 358-364, ISSN 0021-9355

Masri BA., Duncan CP., Adams KR., Nqui-Yen J., \& Smith J. (1995). Streptomycin-loaded bone cement in the treatment of tuberculous osteomyelitis: an adjunct to conventional therapy. Canadian Journal Surgery, Vol. 38, No 1, (February 1995), pp. 64-68, ISSN 0008-428X

Masri BA., Duncan CP., \& Beauchamp CP. (1998). Long term elution of antibiotics from bone cement: an in vivo study using the prosthesis of antibiotic-loaded acrylic cement (PROSTALAC) system. Journal Arthroplasty, Vol.13, No 3, (April 1998), pp. 331-338, ISSN 0883-5403

Matsuno H., Yudoh K., Hashimoto M., Himeda Y., Miyoshi T., Yoshida K., \& Kano S. (2006). A new antibacterial carrier of hyaluronic acid. Journal Orthopaedic Science, Vol. 11, No 5, (October 2006), pp. 497-504, ISSN 0949-2658

McLaren AC., \& Miniaci A. (1986). In vivo study to determine the efficacy of cancellous bone graft as a delivery vehicle for antibiotics. Proceeding of $12^{\text {th }}$ Annual Meeting of the Society for Biomaterials, Minneapolis-St Paul, Minnesota, USA, September 1986

McLaren AC. (1988). Antibiotic impregnated bone graft. Postop levels of vancomycin and tobramycin. Proceeding of Orthopaedic Trauma Association Annual Meeting, BostonMass, USA, September 1998

McLaren AC. (2004). Alternative materials to acrylic bone cement for delivery of depot antibiotics in orthopaedic infections. Clinical Orthopaedics Related Research, Vol. 427, (October 2004), pp. 101-106, ISSN 0009-921X

Mehta S., Humphrey JS., Dchenkmann DI., Seaber AV., \& Vail TP. (1996). Gentamicin distribution from collagen carrier. Journal Orthopaedic Research, Vol. 14, No 5, (September 1996), pp. 749-754, ISSN 0736-0266

Mendel V., Simanowski HJ., Scholz HC., \& Heymman H. (2005). Therapy with gentamicinPMMA beads, gentamicin-collagen sponge, and cefazolin for experimental osteomyelitis due to Staphylococcus aureus in rats. Archives Orthopaedic Trauma Surgery, Vol. 125, No 6, (July 2005), pp. 363-368, ISSN 0936-8051

Mohanty SP., Kumar MN., \& Murthy NS. (2003). Use of antibiotic-loaded polymethylmethacrylate beads in the management of musculoskeletal sepsis-a retrospective study. Journal of Orthopaedics Surgery, Vol. 11, No 1 (January 2003), pp. 73-79, ISSN 1022-5536 
Nandi SK., Munkeherjee P., Ray S., Kundu B., De DK., \& Basu D. (2009). Local antibiotic delivery systems for the treatment of osteomyelitis. - A review. Materials Science and Engineering, Vol. 29, No 8 (October 2009), pp. 2478-2485, ISSN 0928-4931

Nelson CL., Griffin FM., Harrison BH., \& Cooper RE. (1992). In vitro elution characteristics of commercially and noncommercially prepared antibiotic PMMA beads. Clinical Orthopaedics Related Research, Vol. 284, (November 1992), pp. 303-309, ISSN 0009-921X

Nelson CL., McLaren SG., Skinner RA., Smeltzer MS., Thomes JR., \& Olsen KM. (2002). The treatment of experimental osteomyelitis by surgical debridement and the implantation of calcium sulfate tobramycin pellets. Journal Orthopaedic Research, Vol. 20, No 4, (July 2002), pp. 643-647, ISSN 0737-0266

Nelson CL. (2004). The current status of material used for depot delivery of drugs. Clinical Orthopaedics Related Research, Vol. 427, (October 2004), pp. 72-78, ISSN 0009-921X

Neut D., van der Belt H., Stokroos L., van Hom JR, van der Mei HC., \& Busscher HJ. (2001). Biomaterial-associated infection of gentamicin-loaded PMMA beads in orthopaedic revision surgery. Journal Antimicrobial Chemotherapy, Vol. 47, No 6, (July 2001), pp. 885-891, ISSN 0305-7453

Nie L., Nicolau DP., Nightingale CH., Browner BD., \& Quintiliani R. (1995). In vitro elution of ofloxacin from a bioabsorbable polymer. Acta Orthopaedica Scandinavica, Vol. 66, No 4, (August 1995), pp. 365-368, ISSN 0001-6470

Noel SP., Courtney H., Bumgardner JD., \& Haggard WO. (2008). Chitosan films: a potential local drug delivery system for antibiotics. Clinical Orthopaedics Related Research, Vol. 466, (June 2008), pp. 1377-1382, ISSN 0009-921X

Organ CH. (1971). The utilization of massive doses of antimicrobial agents with isolation perfusion in the treatment of chronic osteomyelitis. Clinical Orthopaedics Related Research, Vol. 76, (October 1971), pp. 185-193, ISSN 0009-921X

Ouedraogo M., Semde R., Some IT., Traore-Ouedraogo R., Guisson IP., Henschel V., Dubois J., Amighi K., \& Ervard B. (2008). Monoolein-water liquid crystalline gels of gentamicin as bioresorbable implants for the local treatment of chronic osteomyelitis: in vitro characterization. Drug development Industrial Pharmacy, Vol. 34, No 7, (July 2008), pp. 753-760, ISSN 0363-9045

Ozaki T., Yoshitaka T., Kunisada T., Dan'ura T., Naito N., \& Inoue H. (1998). Vancomycinimpregnated polymethylmethacrylate beads for methicillin-resistant Staphylococcus aureus (MRSA) infection: report of two cases. Journal Orthopaedic Science, Vol. 3, No 3, (June 1998), pp., 163-168, ISSN 0949-2658

Patzakis MJ., \& Wilkins J. (1989). Factors influencing infection rate in open fracture wounds. Clinical Orthopaedics Related Research, Vol. 243, (June 1989), pp. 36-40, ISSN 0009921X

Patzakis MJ., Mazur K., Wilkins J., Sherman R., \& Holtom P. (1993). Septopal beads and autogenous bone grafting for bone defects in patients with chronic osteomyelitis. Clinical Orthopaedics Related Research, Vol. 295, (October 1993), pp. 112-118, ISSN 0009-921X

Perry CR., \& Pearson RL. (1991). Local antibiotic delivery in the treatment of bone and joint infections. Clinical Orthopaedics Related Research, Vol. 263, (February 1991), pp. 215226, ISSN 0009-921X 
Popham GJ., Mangino P., Seligson D., \& Henry SL. (1991). Antibiotic-impregnated beads. Part II: Factors in antibiotic selection. Orthopaedic Review, Vol. 20, No 4, (April 1991), pp. 331-337, ISSN 0094-6591

Rao KP. (1995). Recent developments of collagen-based materials for medical applications and drug delivery systems. Journal Biomaterial Science, Vol. 7, No 7, (July 1995), pp. 623-645, ISSN 0920-5063

Raut W., Siney PD., \& Wroblewski BM. (1995). One-stage revision of total hip arthroplasty for deep infection. Long-term follow-up. Clinical Orthopaedics Related Research, Vol. 321, (December 1995). Pp. 202-207, ISSN 0009-921X

Reddi AH. (1985). Implant-stimulated interface reactions during collagenous bone matrixinduced bone formation. Biomedical materials Research, Vol. 19, No 3, (March 1985), pp. 233-239, ISSN 0021-9304

Rhyu KH., Jung MH., Yoo JJ., Seong SC., \& Kim HJ. (2003). In vitro release of vancomycin from vancomycin-loaded blood coated demineralized bone. International Orthopaedics, Vol. 27, No 1, (January 2003), pp. 53-55, ISSN 0341-2695

Rissing JP. (1997). Antimicrobial therapy for chronic osteomyelitis. Clinical Infectious Diseases, Vol. 25, No 6, (December 1997), pp. 1327-1333, ISSN 1058-4838

Rushton N. (1997). Applications of local antibiotic therapy. European Journal Surgery, Vol.163, Suppl. 578, (September 1997), pp. 27-30, ISSN 1102-416X

Ruszcak Z., \& Friess W. (2003). Collagen as a carrier for on-site delivery on antibacterial drugs. Advanced Drug Delivery Reviews, Vol. 55, No 12, (November 2003), pp. 16791698, ISSN 0169-409X

Sampath SS., Garvin KL., \& Robinson DH. (1992). Preparation and characterization of biodegradable poly(L-lactic acid) gentamicin delivery systems. International Journal of Pharmaceutics, Vol. 78, No 1, (January 1992), pp. 165-174, ISSN 0378-5173

Santschi EM., \& McGarvey L. (2003). In vitro elution of gentamicin from Plaster of Paris beads. Veterinary Surgery, Vol. 32, No 2, (March-April 2003), pp. 128-133, ISSN 01613499

Schierhoz JM., Steinhauser H., Rump AF., Berkels R., \& Pulverer G. (1997). Controlled release of antibiotics from biomedical polyurethanes: morphological and structural features. Biomaterials, Vol. 18, No 12, (June 1997), pp. 839-844, ISSN 0142-9612

Seligson D., Popham GJ., Voos K., Henry SL., \& Faghri M. (1993). Antibiotic-leaching from polymethylmethacrylate beads. Journal Bone Joint Surgery, Vol. 75-A, No 5, (May 1993), pp. 714-720, ISSN 0021-9355

Shinto Y., Uchida A., Korkusuz F., Araki N., \& Ono K. (1992). Calcium Hydroxyapatite ceramic used as a delivery system for antibiotics. Journal Bone Joint Surgery, Vol. 74B, No 4, (July 1992), pp. 600-604, ISSN 0301-620X

Shirtliff ME., Calhoun JH., \& Mader JT. (2002). Experimental osteomyelitis treatment with antibiotic-impregnated Hydroxyapatite. Clinical Orthopaedics Related Research, Vol. 401, (August 2002), pp. 239-247, ISSN 0009-921X

Soundrapandian C., Sa B., \& Datta S. (2009). Organic-inorganic composites for bone drug delivery. AAPS PharmSciTech, Vol. 10, No 4, (December 2009), pp. 1158-1171, ISSN 1530-9932

Stemberger A., Grimm H., Boder F., Rahn HD., \& Ascherl R. (1997). Local treatment of bone and soft tissue infections with the collagen-gentamicin sponge. European journal Surgery Supplement, Vol. 578, (January 1997), pp. 17-26, ISSN 1102-416X 
Taylor EW. (1997). Surgical infection: current concerns. European Journal Surgery, Vol. 163, Suppl. 578, (June 1997), pp. 5-9, ISSN 1102-416X

Thies C. (1982). Microcapsules as drug delivery devices. Critical Reviews Biomedical Engineering, Vol. 8, No 4, (April 1982), pp. 335-383, ISSN 0278-940X

Tomczak RL., Dowdy N., Storm T., Lane J., \& Coldarella D. (1989). Use of ceftazidimeimpregnated polymethylmethacrylate beads in the treatment of Pseudomonas osteomyelitis. Journal Foot Surgery, Vol. 28, No 6, (November-December 1989), pp. 542-546, ISSN 0449-2544

Tonetti MS., Cortellini P., Carnevale G., Cattabriga M., de Sanctis M., \& Pini-Prato GP. (1998). A controlled multicenter study of adjunctive use of tetracycline periodontal fibers in mandibular class II furcations with persistent bleeding. Journal Clinical Periodontology, Vol. 25, No 9, (September 1998), pp. 728-736, ISSN 0303-6979

Trafny EA., Stepinska M., Antos M., \& Grzybowski J. (1995). Effect of free and liposome encapsulated antibiotics on adherence to Pseudomonas aeruginosa to collagen type I. Antimicrobial Agents Chemotherapy, Vol. 39, No 12, (December 1995), pp. 26452649, ISSN 0066-4804

Trafny EA., Grzybowski J., Olszowska-Golec M., Antos M., \& Struzyna J. (1996). Antipseudomonal activity of collagen sponge with liposomal polymyxin B. Pharmacological Research, Vol. 33, No 1, (January 1996), pp. 63-65, ISSN 1043-6618

Tredwell S., Jackson J., Hamilton D., Lee V., \& Burt H. (2006). Use of fibrin sealants for the localized controlled release of cefazolin. Canadian Journal Surgery, Vol. 49, No 5, (October 2006), pp. 347-352, ISSN 0008-428X

Tsourvakas S., Hatzigrigoris P., Tsibinos A., Kanellakopoulou K., Giamarellou H., \& Dounis E. (1995). Pharmacokinetic study of fibrin clot-ciprofloxacin complex: an in vitro and in vivo experimental investigation. Archives Orthopaedic Trauma Surgery, Vol. 114, No 5, (June 1995), pp. 295-297, ISSN 0936-8051

Tsourvakas S., Alexandropoulos C., Karatzios C., Egnatiadis N., \& Kampagiannis N. (2009). Elution of ciprofloxacin from acrylic bone cement and fibrin clot: an in vitro study. Acta Orthopaedica Belgica, Vol. 75, No 4, (August 2009), pp. 537-542, ISSN 0001-6462

Ueng SW., Wei FC., \& Shih CH. (1997). Management of large infected tibial defects with antibiotic beads local therapy and staged fibular osteoseptocutaneous free transfer. Journal of Trauma, Vol. 43, No 2, (August 1997), pp. 268-274, ISSN 0022-5282

von Eiff C., Bettin D., Proctor RA., Lindner N., Winkelmann W., \& Peters G.(1997). Recovery of small colony variants of Staphylococcus aureus following gentamicin bead placement for osteomyelitis. Clinical Infectious Diseases, Vol. 25, No 5, (November 1997), pp. 1250-1251, ISSN 1058-4838

Wachol-Drewek Z., Pfeiffer M., \& Scholl E. (1996). Comparative investigation of drug delivery of collagen implants saturated in antibiotics solutions and a sponge containing gentamicin. Biomaterials, Vol. 17, No 17, (September 1996), pp. 17331738, ISSN 0142-9612

Wahlig H., Dingeldein E., Bergmann R., \& Reuss K. (1978). The release of gentamicin from polymethylmethacrylate beads. An experimental and pharmacokinetic study. Journal Bone Joint Surgery, Vol. 60-B, No 2, (May 1978), pp. 270-275, ISSN 0301-620X

Walenkamp GH. (1989). Small PMMA beads improve gentamicin release. Acta Orthopaedica Scandinavica, Vol. 69, No 6, (December 1989), pp. 668-669, ISSN 0001-6470 
Walenkamp GH. (1997). Chronic osteomyelitis. Acta Orthopaedica Scandinavica, Vol. 68, No 5, (October 1997), pp.497-506, ISSN 0001-6470

Wei G., Kotoura Y., Oka M., Yamamuto T., Wada R., Hyon SH., \& Ikada Y. (1991). A bioabsorbable delivery system for antibiotic treatment of osteomyelitis. The use of lactic acid oligomer as a carrier. Journal bone joint Surgery, Vol. 73-B, No 2, (March 1991), pp. 246-252, ISSN 0301-620X

Whiteside LA. (1994). Treatment of infected total knee arthroplasty. Clinical Orthopaedic Related Research, Vol. 299, (February 1994), pp. 169-172, ISSN 0009-921X

Wilson KJ., Cierny G., Adams KR., \& Mader JT. (1988). Comparative evaluation of the diffusion of tobramycin and cefotaxime out of antibiotic-impregnated polymethylmethacrylate beads. Journal Orthopaedic Research, Vol. 6, No 2, (March 1988), pp. 279-286, ISSN 0736-0266

Wininger DA., \& Fass RJ. (1996). Antibiotic-impregnated cement and beads for orthopedic infections. Antimicrobial Agents Chemotherapy, Vol. 40, No 12, (December 1996), pp. 2675-2679, ISSN 0066-4804

Witso E., Persen L., Loseth K., Benum P., \& Bergh K. (2000). Cancellous bone as an antibiotic carrier. Acta Orthopaedica Scandinavica, Vol. 71, No 1, (February 2000), pp.80-84, ISSN 0001-6470

Woolverton CJ., Fulton JA., Salstrom SJ., Hayslip J., Haller NA., Wildroudt ML., \& McPhee M. (2001). Tetracycline delivery from fibrin controls peritoneal infection without measurable systemic antibiotic. Journal Antimicrobial Chemotherapy, Vol. 48, No 6, (December 2001), pp. 861-867, ISSN 0305-7453

Younger AS., Duncan CP., \& Masri BA. (1998). Treatment of infection associated with segmental bone loss in the proximal part of the femur in two stages with use of an antibiotic loaded interval prosthesis. Journal Bone Joint Surgery, Vol. 80-A, No 1, (January 1998), pp. 60-69, ISSN 0021-9355

Zilch H., \& Lambiris E. (1986). The sustained release of cefotaxim from a fibrin-cefotaxim compound in treatment of osteitis. Pharmacokinetic study and clinical results. Archives Orthopaedic Trauma Surgery, Vol. 106, No 1, (January 1986), pp. 36-41, ISSN 0936-8051 


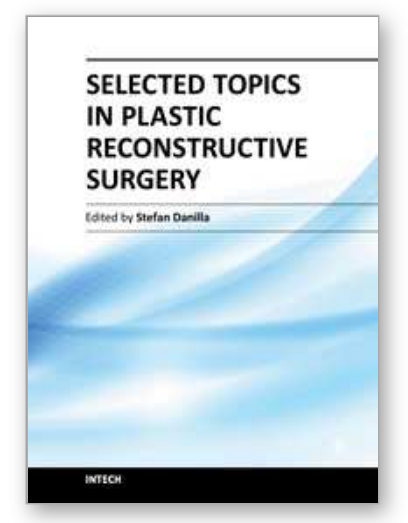

\author{
Selected Topics in Plastic Reconstructive Surgery \\ Edited by Dr Stefan Danilla
}

ISBN 978-953-307-836-6

Hard cover, 242 pages

Publisher InTech

Published online 20, January, 2012

Published in print edition January, 2012

Plastic Surgery is a fast evolving surgical specialty. Although best known for cosmetic procedures, plastic surgery also involves reconstructive and aesthetic procedures, which very often overlap, aiming to restore functionality and normal appearance of organs damaged due to trauma, neoplasm, ageing tissue or iatrogenesis. First reconstructive procedures were described more than 3000 years ago by Indian surgeons that reconstructed nasal deformities caused by nose amputation as a form of punishment. Nowadays, many ancient procedures are still used like the Indian forehead flap for nasal reconstruction, but as with all fields of medicine, the advances in technology and research have dramatically affected reconstructive surgery.

\title{
How to reference
}

In order to correctly reference this scholarly work, feel free to copy and paste the following:

Stefanos Tsourvakas (2012). Local Antibiotic Therapy in the Treatment of Bone and Soft Tissue Infections, Selected Topics in Plastic Reconstructive Surgery, Dr Stefan Danilla (Ed.), ISBN: 978-953-307-836-6, InTech, Available from: http://www.intechopen.com/books/selected-topics-in-plastic-reconstructive-surgery/localantibiotic-therapy-in-the-treatment-of-bone-and-soft-tissue-infections

\section{INTECH}

open science | open minds

\section{InTech Europe}

University Campus STeP Ri Slavka Krautzeka 83/A 51000 Rijeka, Croatia Phone: +385 (51) 770447

Fax: +385 (51) 686166 www.intechopen.com

\section{InTech China}

Unit 405, Office Block, Hotel Equatorial Shanghai No.65, Yan An Road (West), Shanghai, 200040, China 中国上海市延安西路65号上海国际贵都大饭店办公楼 405 单元 Phone: +86-21-62489820

Fax: $+86-21-62489821$ 
(C) 2012 The Author(s). Licensee IntechOpen. This is an open access article distributed under the terms of the Creative Commons Attribution 3.0 License, which permits unrestricted use, distribution, and reproduction in any medium, provided the original work is properly cited. 